\title{
A Functional Organization of ON and OFF Pathways in the Rabbit Retina
}

\author{
Stewart A. Bloomfield ${ }^{1}$ and Robert F. Miller \\ Departments of Ophthalmology, and Physiology and Biophysics, Washington University School of Medicine, \\ St. Louis, Missouri 63110
}

\begin{abstract}
Intracellular electrophysiological recordings were obtained from amacrine and ganglion cells in an isolated, superfused retinaeyecup preparation of the rabbit. Cells were characterized physiologically, after which cell-staining was accomplished by intracellular iontophoresis of HRP. A computer-assisted image-processing system was used to study the dendritic stratification pattern of HRP-labeled neurons within the inner plexiform layer (IPL). Our results support the concept that the IPL is functionally divided into a distal OFF region and proximal $O N$ layer. $\mathrm{ON}$ and OFF ganglion and amacrine cells show dendritic arborizations consistent with this division and ON-OFF ganglion cells have processes in both portions of the IPL. It appears that these functional subdivisions of the IPL reflect excitatory, but not necessarily inhibitory, inputs. Thus, the pattern of dendritic arborization of a cell appears to predict its physiological response polarity, regardless of the type of inhibition it receives.
\end{abstract}

A characteristic feature of the vertebrate retina is the separation of visual information into two separate and parallel ON and OFF pathways. Hartline (1938) first demonstrated this phenomenon, showing that ganglion cells could be categorized into three distinct groups-ON, OFF, or ON-OFF-based on their discharge pattern to the brightening and dimming of a focal light stimulus. For many years the cellular origin of this ON/OFF dichotomy was unknown. Studies utilizing intracellular recording techniques have now established that the bipolar cells are the first ncuronal elements that segregate $O N$ and OFF channels (Kaneko, 1970; Werblin and Dowling, 1969). Physiological studies indicate that bipolar cells directly mediate the ON/OFF activity of ganglion and amacrine cells of the inner retina (Miller and Dacheux, 1976b; Naka, 1977; Slaughter and Miller, 1981; Wunk and Werblin, 1979). According to this scheme, the ON bipolars release an excitatory transmitter in the light, which provides $\mathrm{ON}$ excitation of $\mathrm{ON}$ and $\mathrm{ON}-\mathrm{OFF}$ ganglion and amacrine cells. Conversely, OFF bipolars underlie the OFF activity of the inner retina by releasing an excitatory transmitter in the dark, with an accelerated release at light offset (Dacheux et al., 1979; Wunk and Werblin, 1979).

An intriguing morphological correlate of the ON and OFF bipolar connections in the inner retina has been suggested by Famiglietti and Kolb (1976). They described a spatial segregation of ON and OFF bipolar connections in the inner plexiform layer (IPL) of the cat retina. They noted that bipolars that make either invaginating or flat contacts with cone pedicles send axons

Received June 4, 1984; revised May 21, 1985; accepted May 23, 1985.

S.A.B.'s work was supported by N.E.I. Training Grant 5T32 EY07507. R.F.M.'s work was supported by N.E.I. Research Grant EY00844.

' Present address: Department of Neurobiology and Behavior, State University of New York, Stony Brook, NY 11794. Correspondence should be sent to this address.

Copyright (c) 1986 Society for Neuroscience $0270-6474 / 86 / 010001-13 \$ 02.00 / 0$ which terminate in different layers of the IPL. They theorized that these neurons could be the morphological counterparts of, respectively, ON and OFF bipolars. According to this scheme, ganglion and amacrine cells that receive direct bipolar cell input should display appropriate dendritic stratification within the IPL. It is now widely recognized that ON and OFF ganglion cells of many species display stratification within the IPL appropriate for direct, presumably excitatory, bipolar cell connections. Thus, ON-cell dendrites ramify within the inner margin of the IPL, whereas OFF cells have processes confined to the outer portions of the IPL (Famiglietti et al., 1977; Nelson et al., 1978; Peichl and Wässle, 1981; Zimmerman and Dowling, 1979).

In the present study we have investigated the functional organization of the rabbit retina, using intracellular electrophysiological recording and HRP-staining techniques. Computerassisted image-processing techniques have been used to analyze the level of dendritic arborization in the IPL. We have found that $O N$ and OFF ganglion and amacrine cells display dendritic arborizations within different layers of the IPL. In addition, $\mathrm{ON}-$ OFF cell dendrites branch through the IPL, presumably to allow for synaptic connections with both types of bipolar cells.

In addition to the more obvious excitatory drive, ganglion cells display inhibitory inputs (Baylor and Fettiplace, 1979; Miller et al., 1977; Wunk and Werblin, 1979). Further, several different ON vs OFF forms of inhibition may occur (Dacheux, 1977; Frumkes et al., 1981). One intriguing question posed by these findings is whether inhibitory schemes also follow the ON/ OFF functional stratification scheme which appears to reflect the position of bipolar cell connections. Data from the present study address this important, unresolved issue. Our findings suggest that the stratification scheme of the IPL reflects the spatial position of excitatory, but not necessarily inhibitory, inputs; thus, only the more direct inputs from bipolars (and perhaps some excitatory amacrines) are reflected in this functional organization of the IPL. Results of this study have been reported in preliminary form (Bloomficld, 1981; Bloomficld and Miller, 1981).

\section{Materials and Methods}

\section{Preparation}

The methods used in this study have been reported previously (Bloomfield and Miller, 1982; Dacheux et al., 1973; Miller and Dacheux, 1973). Experiments were performed on adult pigmented rabbits that were anesthetized with an intraperitoneal injection of urethane (Sigma) and a local injection of lidocaine ( $2 \%$ Xylocaine, Astra) to the eyelids and surrounding tissue. The eye was then enucleated under dim red light, hemisected, and the anterior portion discarded. Following removal of the vitreous humor with an ophthalmic sponge, the retina-eyecup was mounted, vitreal side up, in a specially designed superfusion chamber. This chamber was then mounted in a light-tight Faraday cage.

Within $3 \mathrm{~min}$ following enucleation, the retina was bathed in a mod- 
ified Ringer's solution which flowed over the vitreal surface of the retina at a rate of $30 \mathrm{ml} / \mathrm{min}$. The Ringer's consisted of $120 \mathrm{~mm} \mathrm{NaCl}, 5 \mathrm{~mm}$ $\mathrm{KCl}, 25 \mathrm{~mm} \mathrm{NaHCO}, 2 \mathrm{~mm} \mathrm{CaCl}, 1 \mathrm{~mm} \mathrm{MgSO}, 0.1 \mathrm{~mm} \mathrm{NaH} \mathrm{PO}_{4}$, $0.8 \mathrm{~mm} \mathrm{Na} \mathrm{NPO}_{4}, 10.0 \mathrm{~mm}$ glucose, and $1 \%$ dialyzed horse serum (Gibco). Oxygenation and a pH of 7.4 were maintained by bubbling the superfusate with a gaseous mixture of $95 \% \mathrm{O}_{2}-5 \% \mathrm{CO}_{2}$. Each retina was typically used for 4-5 hr.

\section{Light stimulation}

A single quartz-iodine lamp ( $250 \mathrm{~W}$, Sylvania) provided white light for a dual-beam optical bench. Light intensity was controlled by calibrated neutral-density wedges (Kodak) from $\log (-6.0)$ to $\log (0.0)$. Maximum irradiance for the top beam (providing diffuse illumination) was 0.100 $\mathrm{mW} / \mathrm{cm}^{2}$, and for the bottom beam (providing small-spot stimuli), 0.055 $\mathrm{mW} / \mathrm{cm}^{2}$, at $\log (0.0)$. This was measured by a radiant flux meter (Hewlett-Packard) which was placed in the stimulus pathway at the point normally occupied by the retina-eyecup. Filters (Fish-Schurmann 6143) were utilized to eliminate IR and UV irradiation. Both light beams were combined by a collecting prism and jointly projected onto the vitreal surface of the retina. Correct focusing and alignment of the various light stimuli on the retina were maintained visually, using a dissecting microscope (Olympus). Rectangular pulses of light were presented by driving electromagnetic shutters (Uniblitz) with an electronic stimulator (Ortec).

We also tested some cells for direction and orientation selectivity, using a penmotor to move a slit of light. The slit was $100 \mu \mathrm{m}$ wide $\times$ $3 \mathrm{~mm}$ long and could be rotated through $180^{\circ}$ using a dove prism.

\section{Electrical recordings}

Intracellular recordings were obtained using micropipettes fashioned from thin-walled triangular tubing (Glass Company of America) on a vertical glass puller (Narashige). Microelectrodes were held in an $\mathrm{Ag}$ / $\mathrm{AgCl}$ holder (WPI), which was visually positioned above the retinal surface using a micromanipulator (Sobotka). The electrodes were then advanced through the retina using a master-slave syringe hydraulic microdrive. To facilitate impalement of neurons, the amplifier was briefly thrown into oscillation by overadjustment of the capacitance compensation. Intracellular recordings were amplified by a high-impedance amplifier (WPI 701). In addition, the transretinal electroretinogram (ERG) was recorded using a DC-coupled instrumentation amplifier (Haer). The ERG was used to monitor the condition of the retina throughout an experiment.

\section{HRP-staining}

Microelectrodes were filled at their tips with $10 \%$ HRP (BoehringerManheim, Grade I HRP) in $0.5 \mathrm{M} \mathrm{K}^{+}$-acetate $(0.1 \mathrm{M}$ Tris buffer, $\mathrm{pH}$ 7.6) and then backfilled with Ringer's. Following physiological characterization of a neuron, the HRP was iontophoretically injected into the cell for up to $10 \mathrm{~min}$, using a $1 \mathrm{nA}$ (P-P), $3 \mathrm{~Hz}$ current. The response of the cell being stained was monitored each minute to ensure that the electrode was still in place. Up to five neurons were stained per retina; the location of each cell was mapped using the optic disk, medullary rays, and visual streak as landmarks.

After staining the last cell in an experiment, the retina remained in the superfusate for at least $1 \mathrm{hr}$ to allow for diffusion/transport of the HRP throughout the cell processes. The retina-eyecup was then removed from the chamber and immediately fixed in $1.5 \%$ glutaraldehyde- $1.5 \%$ paraformaldehyde ( $\mathrm{pH} 7.3,0.1 \mathrm{~m}$ phosphate buffer) for $10 \mathrm{~min}$. The retina was then separated from the pigment epithelium and washed in Ringer's for $16 \mathrm{hr}$ at $4^{\circ} \mathrm{C}$.

The chromagen used for the HRP reaction was benzidine dihydrochloride, based on the protocol described by Mesulam (1976). Following the reaction, the retina was dehydrated, cleared, and flat-mounted on a microscope slide in Permount (Fisher Scientific). Stained cells were photographed (Nikon) and drawn with the aid of a camera lucida (Jena). For sectioning, retinas were removed from the Permount by washing in xylene. They were then trimmed around each stained cell and embedded in JB-4 medium (Polysciences). Vertical sections, 20-40 $\mu \mathrm{m}$ thick, were sectioned with a steel knife on a rotary microtome (American Optical).

\section{Determination of dendritic stratification in the IPL}

To determine the dendritic stratification pattern, flat-mounted, HRPstained ganglion and amacrine cells were logged into an Image Processing Computer System consisting of a Zeiss light microscope with a motor-driven stage, controlled by a PDP-12 computer. The computer regulated stepping motors connected to the $x, y$, and $z$ axis (focal) adjustments of the microscope stage. A $100 \times$ oil-immersion lens (Zeiss) was used to visualize the cell and its processes. By sampling image points at 3-6 $\mu \mathrm{m}$ intervals along dendritic processes of a cell, data were collected for three-dimensional reconstruction of the cell. The program provided considerable assistance to the operator for achieving reproducibility of the cell structure.

The computer could then recompose the cell and display the structure at any orientation about the $x, y$, and $z$ axes. A $90^{\circ}$ rotation about the $x$ axis from the flat-mount $\left(0^{\circ}\right)$ view provided a cross-sectional view of the neuron, permitting visualization of the level of stratification of dendritic processes in the IPL. The IPL borders were marked by optically estimating the boundaries of the two neighboring cellular layers (inner nuclear and ganglion cell). This was achieved by adjusting the condenser "out of focus" to allow clear visualization of the cell perikarya. The borders were then logged into the computer using the depth at whicl the cell bodies began to defocus, indicating the beginning of the IPL We have estimated the error in this technique, among experienced workers, to be 2-3 $\mu \mathrm{m}$. Computer reconstructions were displayed on an oscilloscope and permanently recorded on a digital plotter (Cal-Comp). Several cells were then vertically sectioned, using a rotary microtome, to corroborate the computer analyses.

For a thorough discussion of the technical and functional aspects of the Image Processing Unit, the reader is directed to Wann et al. (1973) and Dierker (1980).

\section{Results}

We examined the morphology and physiology of 24 ganglion and amacrine cells (Bloomfield, 1981). These neurons were physiologically characterized as ON, OFF, or ON-OFF on the basis of the intracellularly recorded postsynaptic response evoked by a 1-2 sec period of intermittent illumination. In the present study, most of the ganglion cells had large cell bodies and presumably fit into the "brisk" category, which includes transient (Y-like), sustained (X-like), and directionally selective cells (Caldwell and Daw, 1978).

About half the cell population was studied with both focal $(200 \mu \mathrm{m})$ and diffuse light stimuli while the remaining half were characterized using diffuse light stimulation alone. In those cells where both focal and diffuse stimuli were used, the validity of identifying the ON- vs OFF-center nature of the cell with diffuse stimuli alone was demonstrated, as the response of the ganglion cell is dominated by the center mechanism. Barlow et al. (1964) and Miller and Dacheux (1975) demonstrated that diffuse light stimulation can be used to discriminate center excitation from surround excitation on the basis of the comparatively longer latency of surround excitation. On the other hand, ON-OFF cells showed similar latency for both ON and OFF excitation, consistent with both pathways' expressing a center type of latency mechanism. Thus, while all general types of ganglion cells (ON, OFF, and ON-OFF) respond to diffuse light stimulation with both $O N$ and OFF discharge, studying the latency of the discharge gives an unambiguous identification of the cell type (Barlow et al., 1964; Miller and Dacheux, 1975).

While the classic characterization of ganglion cells as $\mathrm{ON}$ or OFF has been based on extracellularly recorded spike activity, intracellular responses often do not display action potentials, probably because of depolarization block associated with the electrode impalement. We therefore classified cells based on the EPSP pattern. On occasion, it was difficult to visualize ON or OFF EPSPs of some ganglion cells because of complex response interactions between fast-depolarizing and hyperpolarizing events. Problems encountered with the ON/OFF classification of cells will be addressed in the Discussion.

\section{Ganglion cells}

ON cells

Figure $1 A$ shows a photomicrograph of an HRP-stained ganglion of the rabbit. This cell displays a dendritic field $250 \mu \mathrm{m}$ across, 

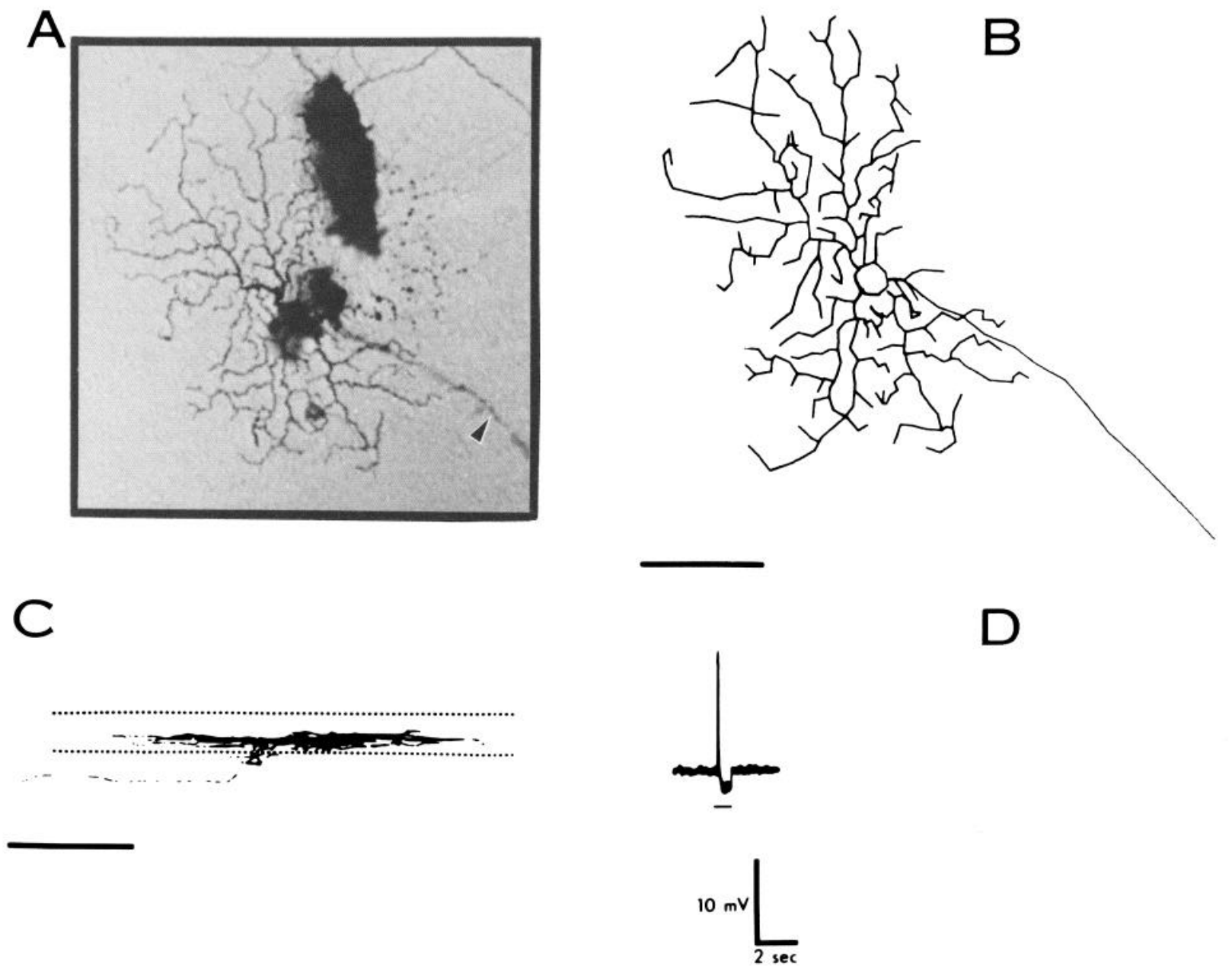

Figure 1. A, Photomicrograph of an HRP-stained ON ganglion cell of the rabbit. This cell displayed a dendritic field of $250 \mu \mathrm{m}$, consisting of wavy, tufted dendrites up to $4 \mu \mathrm{m}$ in diameter. Note the axon which runs at the lower right of the figure (arrowhead). $B$, Computer reconstruction of the same ON ganglion cell illustrated in $A$. Reconstruction is in three dimensions, with a flat-mount view presented. Calibration bar, $100 \mu \mathrm{m}$. $C$, Computer reconstruction of the ON ganglion cell of $A$ and $B$, rotated $90^{\circ}$ about the $x$ axis. This offers a vertical view of the level of the dendritic stratification within the IPL. The dotted lines represent the IPL borders optically determined with the inner nuclear layer at top. The dendrites of this cell branch in a unistratified manner within the proximal IPL. Note the axon that lies vitreal to the IPL (bottom left). Calibration bar, 100 $\mu \mathrm{m}$. $D$, Intracellularly recorded response of the $\mathrm{ON}$ ganglion cell in $A-C$, evoked by diffuse illumination. The response consisted of a transient generated at light onset, followed by a hyperpolarization for the stimulus duration. Dark bar beneath the response represents a 1 sec light stimulus. Light intensity $=\log (-3.0)$; maximum irradiance, $\log (0.0)=0.1 \mathrm{~mW} / \mathrm{cm}^{2}$.

made up of wavy, tufted processes up to $4 \mu \mathrm{m}$ in diameter. The soma of this neuron is $20 \mu \mathrm{m}$ in diameter, quite large in comparison with other cells encountered during this investigation. The cell body is the probable site of electrode penetration, as evidenced by the "spillage" of HRP reflected by the extracellular pool of stain. This neuron is easily identified as a ganglion cell, for its soma lies proximal to the dendrites within the ganglion cell layer (GCL) and an axon emerges from the soma (arrowhead) that could be followed to the optic disk.

Figure $1 B$ is a computer reconstruction of the cell in flatmount. This drawing is an accurate replication of the neuron, illustrating not only the dendritic processes and branch points, but also an outline of the soma. Since the computer reconstruction consists of three-dimensional data, it is possible to rotate the cell $90^{\circ}$ about the $x$ axis to visualize the dendritic stratification as seen in Figure $1 C$. The dotted lines represent the borders of the IPL, optically determined; in this and all subsequent figures, the vitreal surface is towards the bottom of the figure. The soma is not illustrated in this drawing, for it can only be logged in two dimensions and appears as a straight line following rotation. The cell dendrites branch laterally within the IPL and ramify in a unistratified manner within the proximal IPL. We have purposely avoided the "a" and "b" terminology of Famiglietti and Kolb (1976) used to describe the sublamination pattern in the cat retina, since we could not find clear histological landmarks that divide the IPL, as the inner retinal circulation does for the cat. We therefore have adopted the terms "distal IPL" and "proximal IPL" to describe the levels of dendritic branching within the inner plexiform layer.

Figure $1 D$ illustrates the intracellularly recorded response of this cell to a diffuse light stimulus consisting of a spike at light onset followed by a hyperpolarization for the stimulus duration. Recordings of this type were commonly encountered in the rabbit and are classified as ON cells because of the excitation displayed at light onset. Dacheux (1977) has described similar ganglion cell responses in the rabbit, in which directional selectivity for a moving slit of light is displayed. Directionally selective properties were not determined for this cell.

Figure $2 A$ is a computer reconstruction of another HRP-stained ganglion cell. This neuron displayed a dendritic field of $450 \mu \mathrm{m}$ across the longest axis, which consisted of radiate-type branching processes. Figure $2 B$ illustrates a $90^{\circ}$ rotation of this computer-reconstructed neuron about the $x$ axis. As was seen for the previous cell, the dendrites arborize in a unistratified manner 

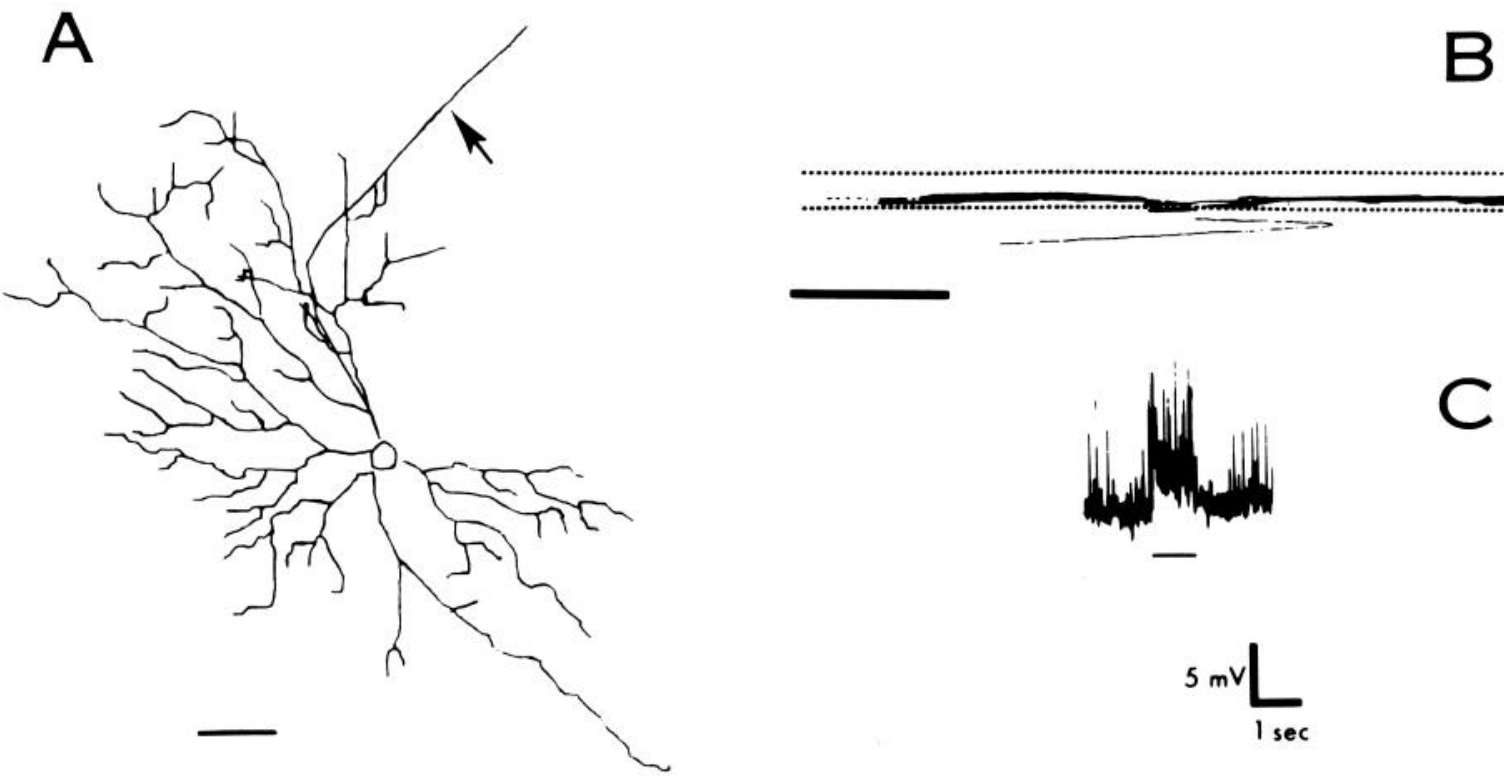

Figure 2. A, Computer reconstruction of an HRP-stained ON ganglion cell. This neuron exhibited a large asymmetrical dendritic field, $450 \mu \mathrm{m}$ across, made up of radiate-type branching dendrites. An axon emerges from the soma and runs towards the optic disk at upper right (arrow). Calibration bar, $50 \mu \mathrm{m}$. B , Reconstruction of the same ganglion cell of $A$ rotated $90^{\circ}$ about the $x$ axis to illustrate the level of dendritic branching in the IPL. The dendrites of this cell branch within a single layer in the proximal IPL. Dotted lines represent the IPL borders. Calibration bar, 50 $\mu \mathrm{m}$. $C$, Intracellularly recorded response of the ganglion cell shown in $A$ and $B$ consisted of a sustained depolarization, accompanied by an increase in spike activity during a $1 \mathrm{sec}$ light stimulus. Light intensity $=\log (-3.0)$; maximum irradiance, $\log (0.0)=0.1 \mathrm{~mW} / \mathrm{cm}^{2}$.
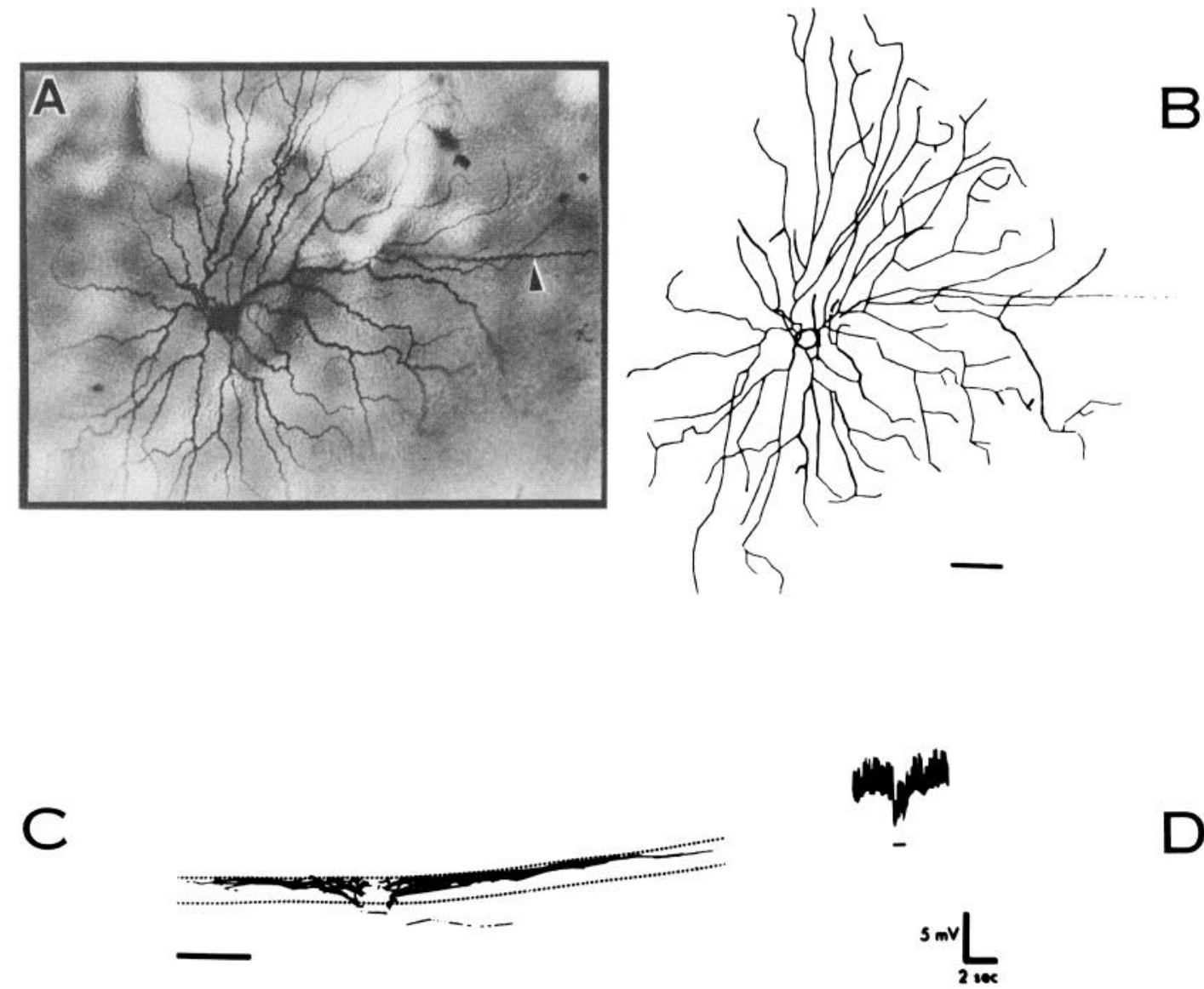

Figure 3. A, Photomicrograph of an HRP-stained OFF ganglion cell. A large dendritic field, $500 \mu \mathrm{m}$ across the longest axis, is made up of coarse dendrites up to $5 \mu \mathrm{m}$ in diameter. Note the axon at right that runs towards the optic disk (arrowhead). $B$, Computer reconstruction in flat-mount $\left(0^{\circ}\right)$ of the ganglion cell illustrated in $A$. Calibration bar, $50 \mu \mathrm{m} . C, 90^{\circ}$ rotation about the $x$ axis of the computer-reconstructed cell illustrated in $B$. The dendrites of this neuron branch in a unistratified manner within the distal IPL. The abrupt bending of processes and IPL borders (dotted lines) at right reflect tissue distortion. Calibration bar, $50 \mu \mathrm{m}$. D. Light-evoked response of the OFF cell consisted of a predominantly sustained hyperpolarization. Light intensity $=\log (-3.0)$; maximum irradiance, $\log (0.0)=0.1 \mathrm{~mW} / \mathrm{cm}^{2}$. 


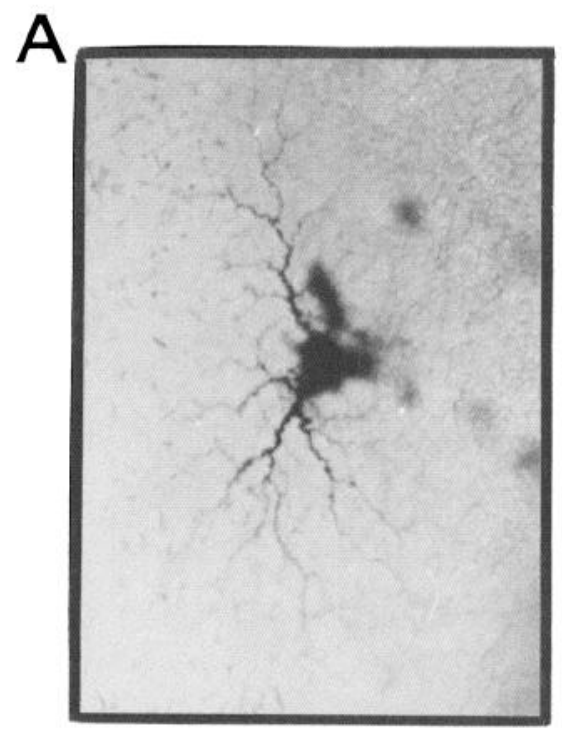

C

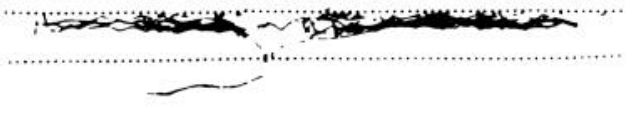

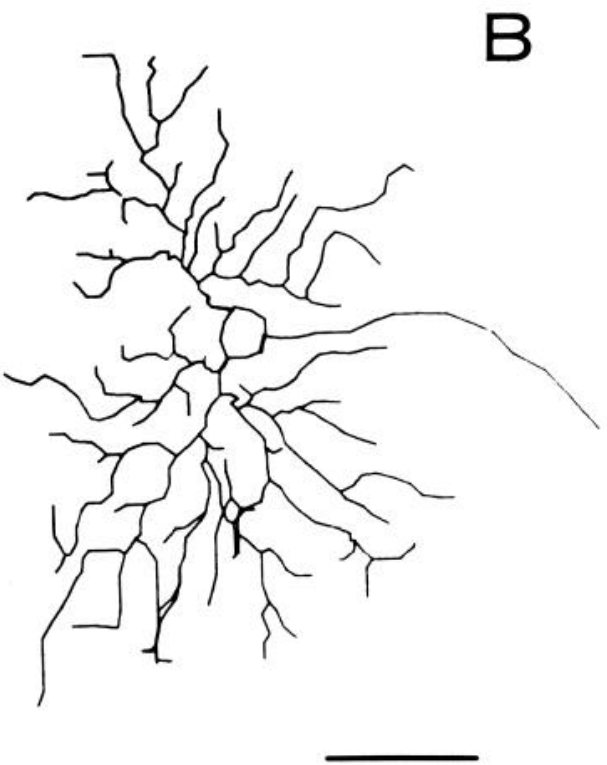

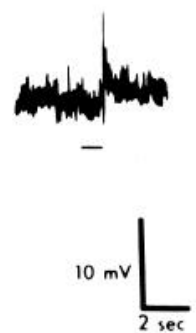

Figure 4. A, Photomicrograph of an HRP-stained OFF ganglion cell. Two primary dendrites branch to form a small dendritic field of approximately $150 \mu \mathrm{m}$ across. Calibration bar, $50 \mu \mathrm{m}$. B. Computer reconstruction of the same ganglion cell illustrated in $A$. Several dendritic branches including the axon were faintly stained and not visible in the photomicrograph, but could be seen with sufficient clarity to log them onto the computer. Calibration bar, $50 \mu \mathrm{m}$. $C$, Computer reconstruction of the cell shown in $A$ and $B$, rotated $90^{\circ}$ about the $x$ axis. Dotted lines represent the IPL borders. The dendrites branch in a unistratified fashion within the distal IPL. Calibration bar, $50 \mu \mathrm{m}$. $D$, Intracellularly recorded response of the $\mathrm{OFF}$ ganglion cell of $A-C$ in response to a diffuse light stimulus. The response consists of a sustained hyperpolarization followed by a spike at light offset. Light intensity $=\log (-3.0)$; maximum irradiance, $\log (0.0)=0.1 \mathrm{~mW} / \mathrm{cm}^{2}$.

within the proximal IPL. Figure $2 C$ shows the sustained ON response evoked in this cell by diffuse light stimulation.

A total of eight physiologically characterized $\mathrm{ON}$ ganglion cells were injected with HRP and examined for the level of dendritic branching in the inner plexiform layer. All exhibited unistratified processes which arborized within the proximal IPL (see Fig. 10).

\section{OFF cells}

Figure $3 A$ is a photomicrograph of an HRP-stained OFF ganglion cell of the rabbit. This neuron displayed coarse dendritic processes, up to $5 \mu \mathrm{m}$ in diameter, which comprised a field of $500 \mu \mathrm{m}$. The cell perikaryon is $25 \mu \mathrm{m}$ in diameter (the largest of any ganglion cell studied here); an axon emerges from it at right (arrow) and runs towards the optic nerve head. Figure $3 B$ illustrates the flat-mount computer reconstruction of this cell, and Figure $3 C$ shows the cell rotated $90^{\circ}$ about the $x$ axis to display the level of dendritic arborization in the IPL. The processes project deep into the IPL and then ramify within the outer portion of that neuropil. This pattern is in contrast to that described for ON ganglion cell dendrites. The response of the latter cell consisted of a sustained hyperpolarization, associated with a decrease of spike activity during illumination (Fig. $3 D$ ).
A photomicrograph of a second OFF ganglion cell is shown in Figure $4 A$. The dendritic field, $200 \mu \mathrm{m}$ across, is comprised of two primary dendrites which branch dichotomously into two complex dendritic trees, exhibiting up to 5 th-order branch points. Figure $4 B$ is a flat-mount $\left(0^{\circ}\right.$ rotation) computer reconstruction of this cell showing all processes, including the axon and some distal dendritic branches that were faintly stained and not visible in the photomicrograph. The primary dendrites project into the distal IPL and ramify laterally within that region (Fig. 4C). The light-evoked response of this OFF cell (Fig. $4 D$ ) consisted of a small sustained hyperpolarization during light, followed by a single spike at stimulus offset.

A total of seven ganglion cells were classified as OFF cells and subsequently stained with HRP. Without exception, the dendrites of these neurons were all found to branch in a unistratified fashion within the distal inner plexiform layer.

\section{ON-OFF cells}

$\mathrm{ON}-\mathrm{OFF}$ ganglion cells constitute a third physiological class of neurons showing $\mathrm{ON}-\mathrm{OFF}$ discharge. Cells that come under the $\mathrm{ON}-\mathrm{OFF}$ heading include local edge detectors, large field units (which display $\mathrm{ON}-\mathrm{OFF}$ responses to diffuse illumination), and directionally selective cells. These cells are readily distinguished 

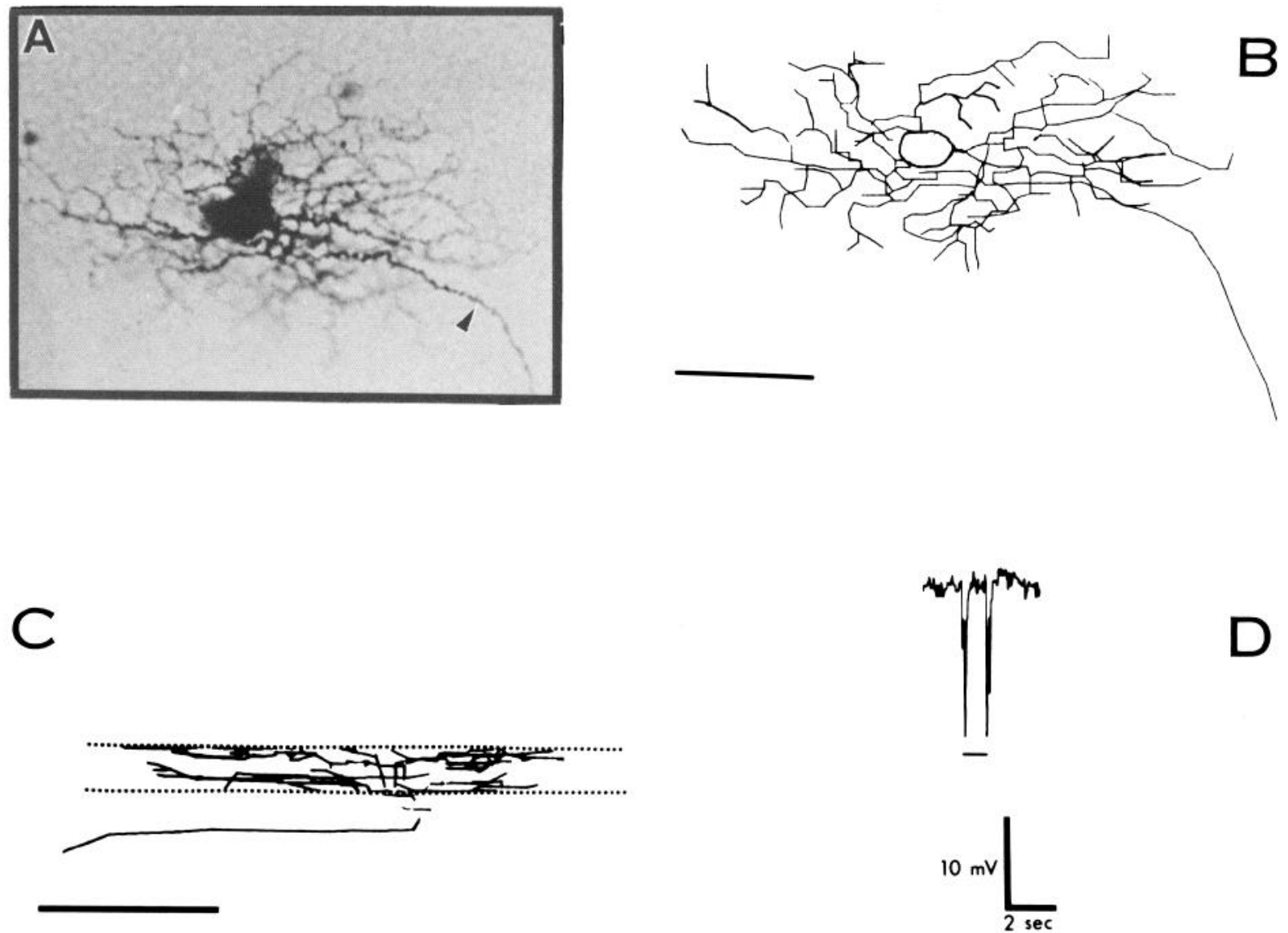

Figure 5. A, Photomicrograph of an HRP-stained ON-OFF ganglion cell of the rabbit. In this flat-mount view, it is clear that not all the dendrites are in focus, indicating that they must stratify in more than a single focal plane. Note the axon running to the optic disk at lower right (arrowhead). $B$, Computer reconstruction of the ON-OFF ganglion cell of $A$. Calibration bar, $50 \mu \mathrm{m}$. Not all the processes were logged onto the computer, owing to limitations in computer storage capacity. $C$, Computer reconstruction of $A$ and $B$ rotated $90^{\circ}$ about the $x$ axis. The dendrites of this cell branch in a bistratified fashion with processes in both the inner and outer regions of the IPL. Calibration bar, $50 \mu \mathrm{m}$. $D$, Intracellularly recorded response of the ON-OFF ganglion cell of $A-C$, evoked by a 1 sec diffuse light stimulus. The light-evoked response is dominated by hyperpolarizations at both light onset and offset (presumably IPSPs). Such ON-OFF "IPSP units" are commonly seen in the rabbit retina (see text). When this cell was first penetrated, ON and OFF excitation was observed. Light intensity $=\log (-3.0)$; maximum irradiance, $\log (0.0)=0.1 \mathrm{~mW} / \mathrm{cm}^{2}$.

from $\mathrm{ON}$ - and OFF-center cells in that the $\mathrm{ON}-\mathrm{OFF}$ responses are found throughout the receptive field and the ON and OFF discharges show (with the possible exception of large field units) nearly equal latencies (Barlow et al., 1964; Miller and Dacheux, 1975).

Electrophysiological evidence suggests that these cells receive inputs from both ON and OFF bipolar cells (Miller and Dacheux, 1976b). In addition, studies of cat retina indicate that ON and OFF bipolar cells send their axons to different regions of the IPL (Nelson et al., 1981). Together, these findings suggest that $\mathrm{ON}-\mathrm{OFF}$ ganglion cells should maintain dendritic processes within different levels of the IPL if direct synaptic connections are made with both classes of bipolar cells.

Figure $5 A$ is a photomicrograph of a physiologically characterized ON-OFF ganglion cell of the rabbit. The dendritic field is quite small-only $125 \mu \mathrm{m}$ across-and consists of a dense maze of intertwining processes. In the flat-mount view, one can determine that not all of the processes are in focus, indicating that they do not all stratify within a single layer. The computer reconstruction seen in Figure $5 B$ is only a partial reconstruction of the cell, owing to the great complexity of the dendritic arborizations and the limited data storage capacity of the computer. However, the $90^{\circ}$ rotation (Fig. $5 C$ ) of the cell confirms that the dendrites ramify in a bistratified branching pattern and send processes to the distal and proximal IPL. The light-evoked response of this ganglion cell consisted of complex hyperpolar- izations at stimulus onset and offset (Fig. 5D). When first impaled, this cell displayed both transient depolarizations and hyperpolarizations similar to those reported for other ON-OFF ganglion cells (Dacheux, 1977; Miller and Dacheux, 1976a). The large hyperpolarizations illustrated are probably IPSPs, exaggerated by depolarization associated with electrode impalement. This cell was tested for directional selectivity, but no clear direction-selective response organization was elicited.

A photomicrograph of a second HRP-stained ON-OFF rabbit ganglion cell is presented in Figure $6 A$. This neuron displays a dense maze of dendrites which form an almost hemisphericalshaped field, $230 \mu \mathrm{m}$ across the long axis. A striking feature of this cell is the highly asymmetric distribution of the dendritic tree, which is almost exclusively confined to the left-hand region, away from the cell body. An axonal process (arrowhead) was also stained and could be followed over $700 \mu \mathrm{m}$ to the optic disk. A $90^{\circ}$ rotation of the flat-mount computer reconstruction (Fig. 6, B, C) clearly shows that the dendrites of this cell branch in a bistratified manner in both halves of the IPL. The intracellularly recorded response (Fig. $6 D$ ) consisted of EPSP-IPSP combinations at both light onset and offset. The similar latencies of the ON and OFF EPSPs (within $20 \mathrm{msec}$ ) confirmed the identity of this unit as an ON-OFF cell (Barlow et al., 1964). The excitatory inputs to this cell are presumably from bipolar cells, while the IPSPs reflect inputs from inhibitory amacrines (Miller, 1979). Note, however, that an initial hyperpolarization 

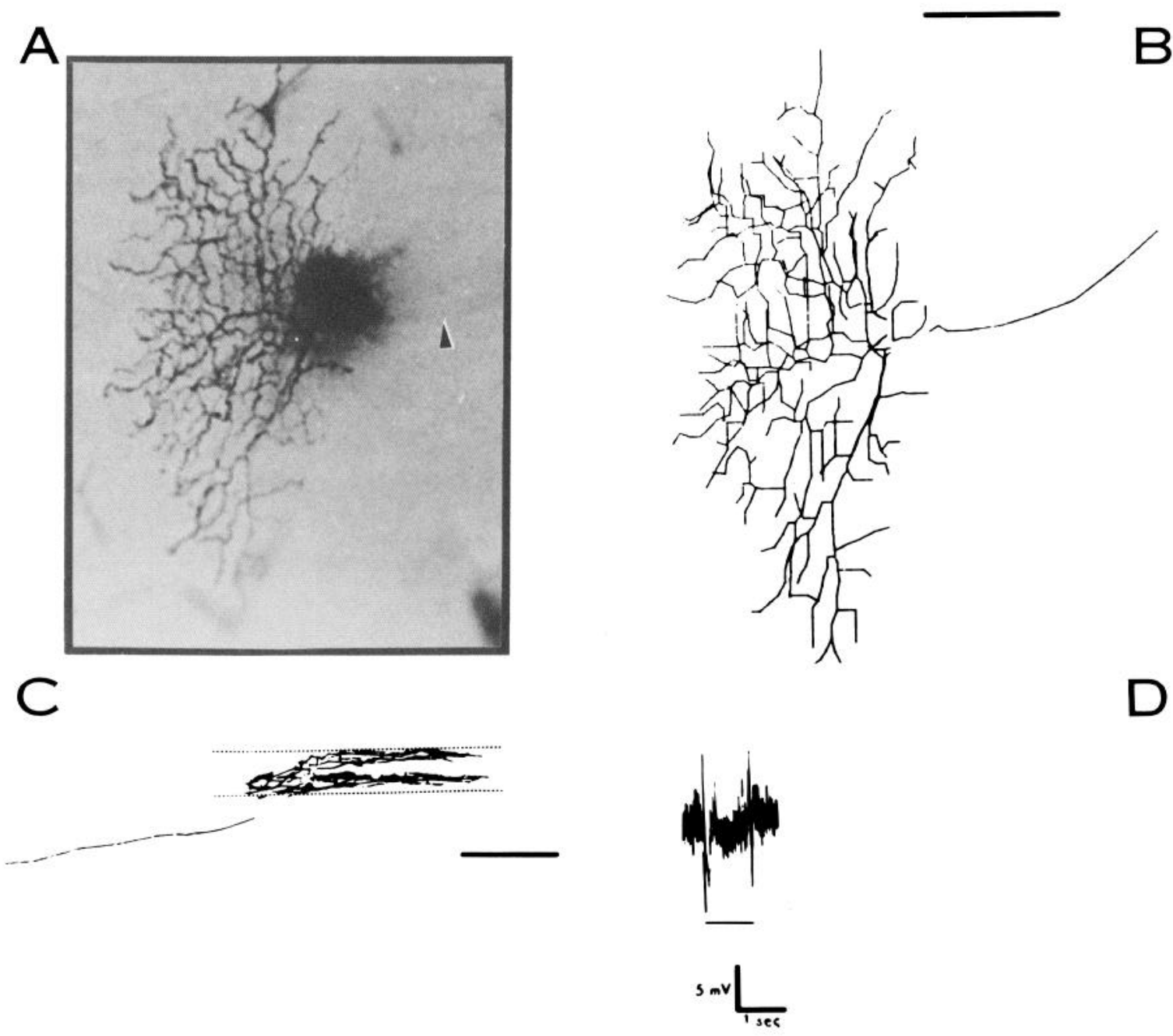

Figure 6. A, Photomicrograph of an HRP-stained ON-OFF ganglion cell. The semicircular-shaped dendritic field, $230 \mu \mathrm{m} \times 80 \mu \mathrm{m}$, consists of a dense maze of tufted dendrites. The axon, out of focus at right (arrowhead), could be followed to the optic disk. $B$, Computer reconstruction of the ON-OFF ganglion cell of $A$. $C$, Computer reconstruction of the cell of $A$ and $B$, rotated $90^{\circ}$ about the $x$ axis. The dendrites of this cell are clearly bistratified, residing within both divisions of the IPL. Calibration bar, $50 \mu \mathrm{m}$. $D$, Intracellularly recorded light response of the cell illustrated in $A-C$, consisting of depolarizing and hyperpolarizing potentials at stimulus onset and offset. Light intensity $=\log (-3.0)$; maximum irradiance, $\log (0.0)=0.1 \mathrm{~mW} / \mathrm{cm}^{2}$.

at light onset precedes the initial EPSP. It is uncertain whether this component is a true IPSP at light onset or a disfacilitatory potential (see Dacheux et al., 1979). This cell was also tested for directional selectivity, with negative results.

Three ON-OFF ganglion cells were examined during this investigation. Two displayed dendritic branching in a bistratified manner, while a third showed a more diffuse dendritic arborization throughout the IPL. Although we excluded directionally selective properties for two of the three cells, we did not perform the appropriate tests for classifying these cells as local edge detectors or large field units. However, at least two of the cells were clearly not large field units, since focal light stimuli elicited an $\mathrm{ON}-\mathrm{OFF}$ response from these cells as well.

\section{Amacrine cells}

If the functional stratification scheme seen for ganglion cells reflects the different levels at which $\mathrm{ON}$ and OFF bipolar axons terminate in the IPL, then amacrine cells should also adhere to this scheme if they receive bipolar input. We studied the level of dendritic arborization for six different amacrine cells. ON/ OFF characterization of these amacrine cell responses was less ambiguous than was the case with ganglion cells, since the ama- crines did not display large hyperpolarizing responses that could mask excitatory potentials.

Figure $7 A$ shows a photomicrograph of an HRP-stained amacrine cell of the rabbit. The cell body is quite small, $10 \mu \mathrm{m}$ in diameter, and actually is displaced within the ganglion cell layer. Two primary dendrites emerge from the soma in a bipolar fashion to form a "bow-tie"-shaped dendritic field $700 \mu \mathrm{m}$ across the major axis. This neuron was identified as an amacrine cell on the basis of its clear lack of an axon and its similar morphology to Golgi-impregnated rabbit amacrine cells, as reported by Hughes (1971).

Figure $7 \mathrm{~B}$ is a flat-mount computer reconstruction of this cell, showing its large, asymmetric dendritic field. A rotation of this reconstructed cell (Fig. $5 C$ ) shows that the dendritic processes ramify in a unistratified manner within the proximal IPL. The intracellularly recorded response of this ON amacrine cell (Fig. $7 D$ ) consists of an initial transient excitatory component (possibly a spike), followed by a rapidly declining plateau phase and a hyperpolarization at light offset.

A special class of rabbit amacrine cells has been denoted "starburst" amacrines because of their intriguing, starburst-like dendritic morphology (Famiglietti, 1981; Famiglietti, 1983; Fa- 

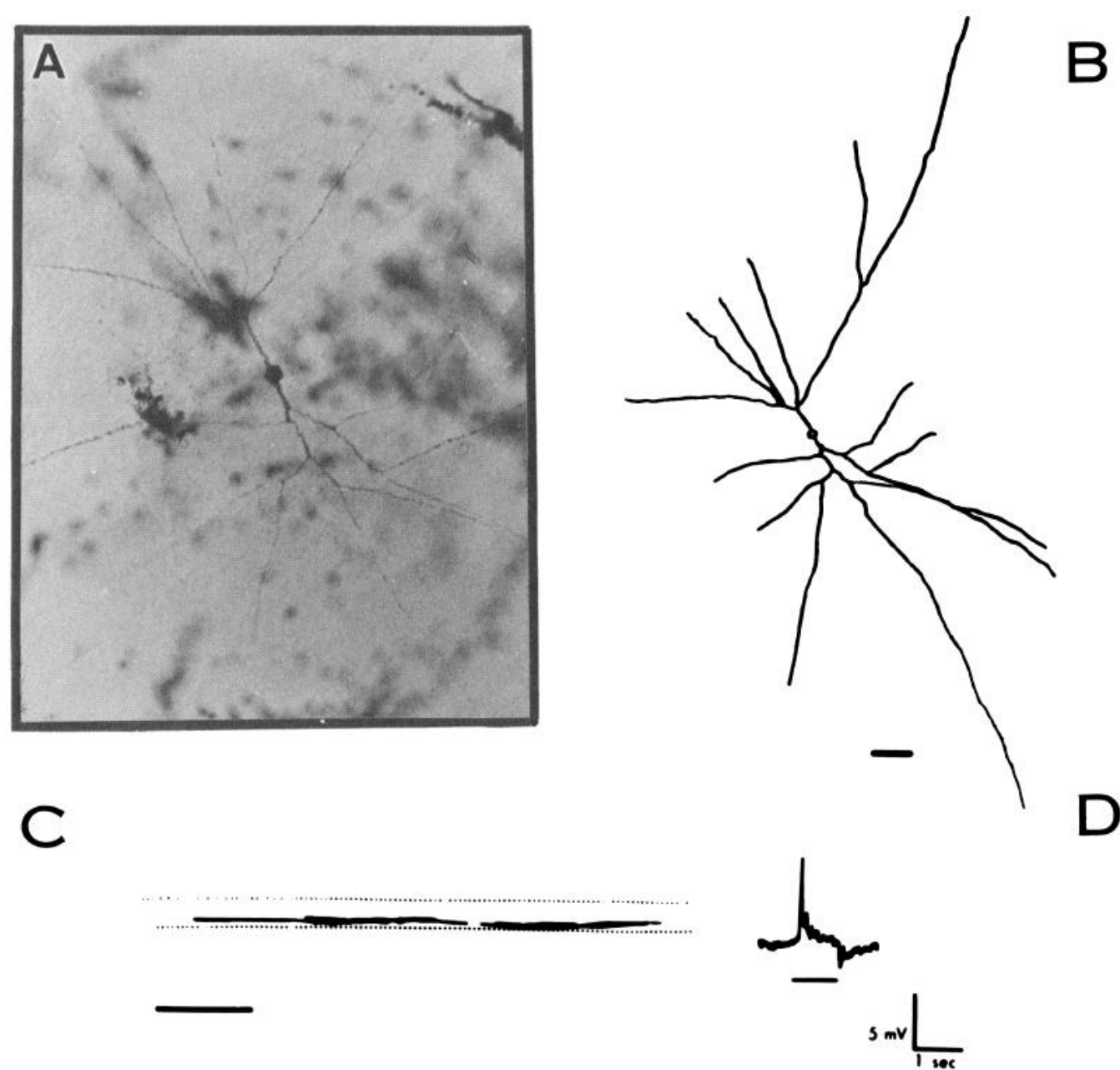

Figure 7. A, Photomicrograph of an HRP-stained ON amacrine cell. This neuron had a small soma, $10 \mu \mathrm{m}$ in diameter, from which two primary dendrites emerged in a bipolar-like fashion to form a "bow-tie"-shaped dendritic field. The cell body is localized within the ganglion cell layer. $B$, Computer reconstruction of the amacrine cell illustrated in $A$. Note the extensive asymmetrical dendritic field, $700 \mu \mathrm{m}$ across the long axis, featuring almost no dendritic overlap. Calibration bar, $50 \mu \mathrm{m}$. $C$, Computer reconstruction rotated $90^{\circ}$ about the $x$ axis. The dendrites branch in a unistratified manner and are limited to the proximal IPL. Calibration bar, $50 \mu \mathrm{m}$. $D$, Intracellularly recorded light-evoked response of the cell illustrated in $A$ and $B$ in response to a diffuse light stimulus. The response consisted of an initial transient depolarizing potential (possibly a spike) and a small transient hyperpolarization at light offset. Light intensity $=\log (-3.0)$; maximum irradiance, $\log (0.0)=0.1 \mathrm{~mW} / \mathrm{cm}^{2}$.

miglietti and Siegfried, 1980; Miller and Bloomfield, 1983). Two types of starburst amacrines have been described: starburst-a cells have their somata within the inner nuclear layer, and starburst-b somata are displaced within the ganglion cell layer. Starburst cell arrangement consists of mirror-images of cells across the IPL. The dendritic trees of these cells ramify in narrowly stratified sublayers of the IPL: the dendrites of starburst-b cells are confined to the proximal IPL, while the dendrites of starburst-a cells ramify within the distal IPL.

Figure 8 shows a retouched photograph of an HRP-stained OFF starburst amacrine. The striking anatomy of this cell clearly identifies it as a starburst amacrine, showing morphology congruent with that of cells identified with the Golgi technique (Famiglietti, 1983). In this cell, the dendrites near the soma were so thin that retouching was necessary to adequately photograph the dendritic tree. Photographs of unretouched dendrites have been published elsewhere (Miller and Bloomfield, 1983): note that the distal dendrites appear somewhat larger than the proximal processes and contain varicosities.

Figure $9 A$ shows a computer reconstruction of the starburst amacrine illustrated in Figure 8. Figure $9 B$ illustrates the branching pattern of the dendrites seen after $90^{\circ}$ computer rotation. The processes are confined to a narrow stratum within the distal
IPL. Figure $9 C$ shows the intracellularly recorded light-evoked hyperpolarization. This cell was impaled close to the visual streak, within $2 \mathrm{~mm}$ of the optic nerve head.

A computer reconstruction of a starburst-b amacrine cell is shown in Figure $9 D$. This cell had a small, displaced cell body, $10 \mu \mathrm{m}$ in diameter, from which seven proximal dendrites emerged. Because of extracellular leakage of HRP, we could not determine whether the proximal processes emerged from a single primary stalk, or were separately connected to the cell body. The almost circular dendritic field consisted of radiate-type branching processes, with little overlap. This cell was located 6 $\mathrm{mm}$ from the optic disk.

Figure $9 E$ shows a $90^{\circ}$ rotation of the starburst neuron of $9 D$, illustrating the unistratified dendritic tree confined to the proximal IPL. The light-evoked response of this ON amacrine cell consisted of an initial transient depolarization at light onset, followed by a sustained plateau phase for the stimulus duration (Fig. $9 F$ ). At light offset, a transient hyperpolarization was seen. We did not detect impulse activity in starburst amacrines. However, we did see obvious spike activity in one "ON" type (nonstarburst) amacrine (see Fig. 10).

A total of six amacrine cells were investigated (see Fig. 10). All recordings were unambiguous with respect to the ON/OFF 


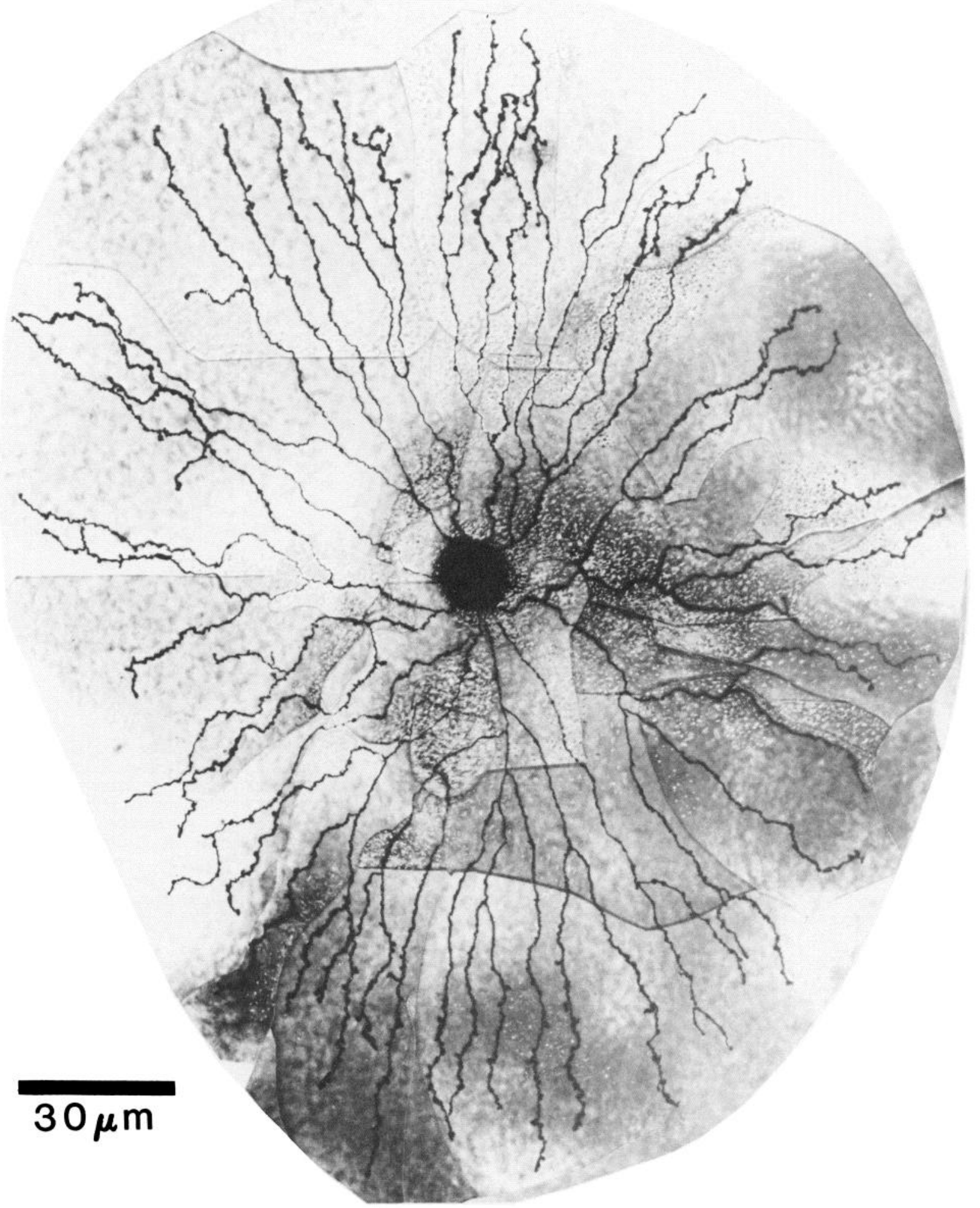

Figure 8. A slightly retouched flat-mount view of an HRP-stained starburst-a amacrine cell. The dendrites near the soma required retouching since they were extremely fine and faintly stained. Note the symmetry of the dendritic branching and the presence of varicosities on distal processes. In this cell it appears that distal branches may be larger than more proximal segments.

classification, and these cells all conformed to the functional stratification scheme displayed by ganglion cells. Unfortunately, physiologically characterized ON-OFF amacrine cells were not successfully labeled with HRP during the course of this study. Figure 10 presents a summary of the ganglion and amacrine cell types seen in this study, grouped according to the level of den- 
A

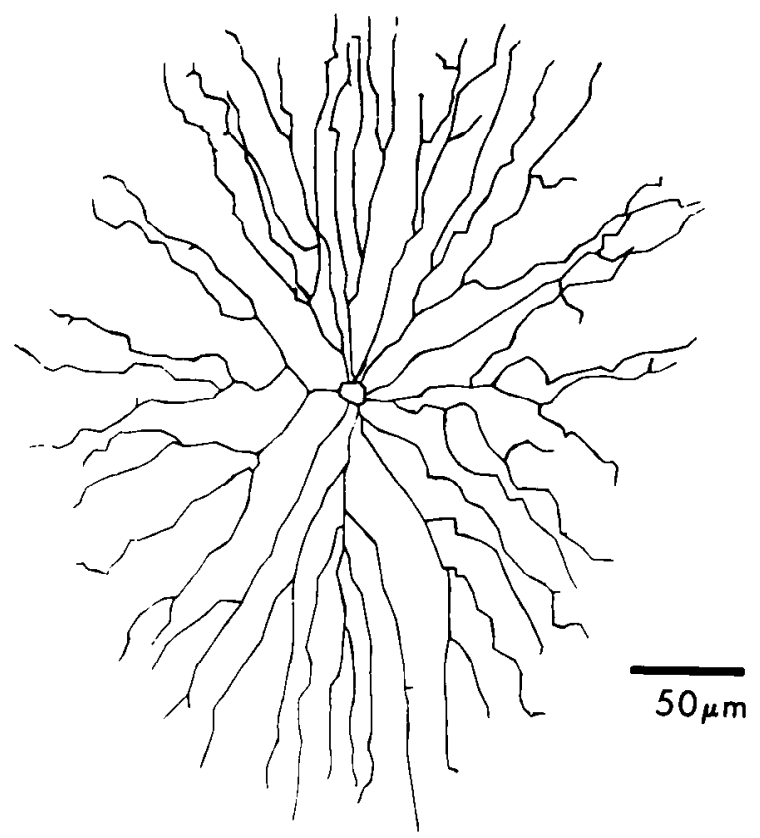

B

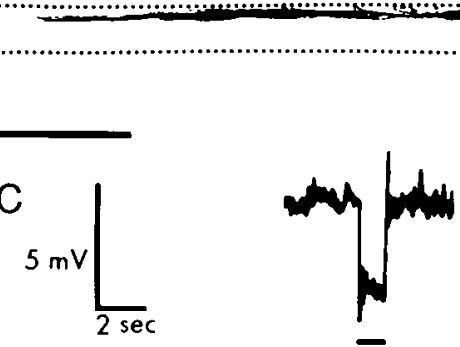

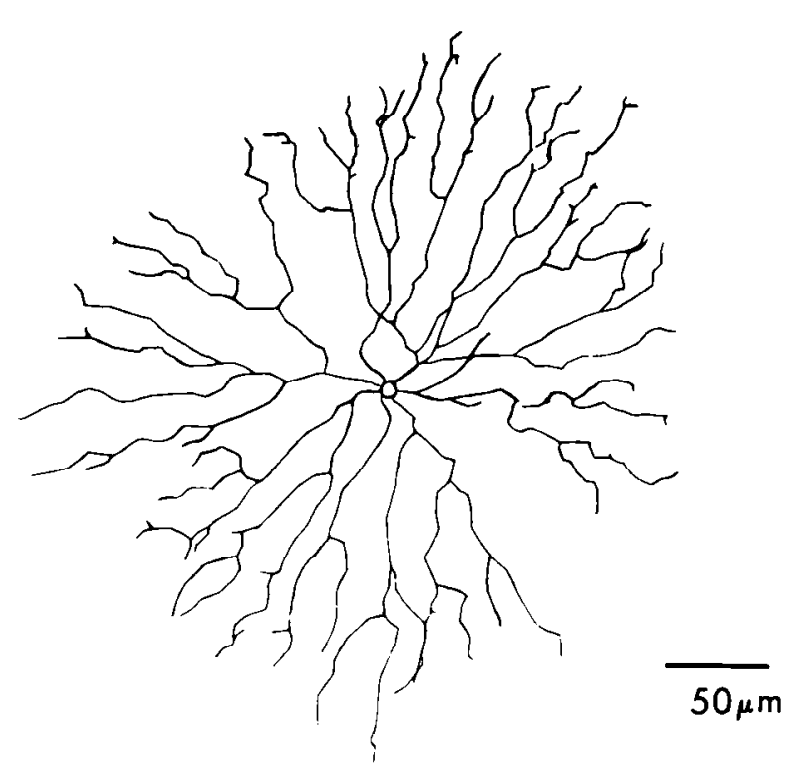

$E$

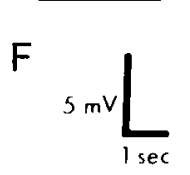

Figure 9. A, Computer reconstruction of the starburst-a amacrine cell illustrated in Figure $8 . B$, Computer reconstruction of $A$ rotated $90^{\circ}$ about the $x$ axis. The dendrites branch in a unistratified manner within the distal IPL. Calibration bar, $50 \mu \mathrm{m}$. $C$, Intracellularly recorded light response of $A$ and $B$, evoked by diffuse illumination, consisted of a sustained hyperpolarization with transient components at stimulus onset and offset. Light intensity $=\log (-3.0)$; maximum irradiance, $\log (0.0)=0.1 \mathrm{~mW} / \mathrm{cm}^{2} . D$, Computer reconstruction of a displaced starburst-b amacrine cell of the rabbit. This cell exhibited a circular dendritic field, $250 \mu \mathrm{m}$ across, displaying long primary processes with numerous peripheral branch points. Varicosities, not shown here, were present along the distal branches, similar to the arrangement shown in Figure 8 . $E$, Computer reconstruction of the cell in $D$ rotated $90^{\circ}$ about the $x$ axis to illustrate the plexiform sublamination pattern. The dendrites ramify in a unistratified manner within the proximal IPL. Dotted lines represent the IPL borders. Calibration bar, $50 \mu \mathrm{m}$. $F$, Intracellularly recorded light response of the cell illustrated in $D$ and $E$, evoked by diffuse illumination. The light response consisted of a transient excitatory potential at light onset, followed by a reduced, sustained depolarization for the stimulus duration. Light intensity $=\log (-3.0)$; maximum irradiance, $\log (0.0)=0.1 \mathrm{~mW} / \mathrm{cm}^{2}$.

dritic branching in the IPL and the physiological response polarity. Each illustrated physiological response was evoked by diffuse light stimulation.

\section{Discussion}

The present study has demonstrated a correlation between the level of dendritic stratification of rabbit ganglion and amacrine cells and the physiological ON, OFF, or ON/OFF response polarity. Of the 24 cells studied here, all conformed to the functional organization of the IPL first described by Famiglietti and Kolb (1976) in the cat: ON cell dendrites stratified within the inner margin of the IPL; dendrites of OFF cells stratified in the distal IPL; while ON-OFF cell dendrites branched throughout the IPL in either a bistratified or diffuse manner. These results suggest that the response polarity of third-order neurons can be predicted by the intralaminar organization of the dendritic arborization, irrespective of other morphological features.

It should be noted that we classified many of our cells as "ON" or "OFF" using a diffuse light stimulus. However, in those cells where center stimulation was used together with diffuse light stimuli, we verified that the polarity of the ganglion cell light response is dominated by the center mechanism. Nonetheless, our findings indicated a clear relationship between the level of dendritic stratification of proximal neurons and their excitatory response to light onset and/or offset, regardless of whether these responses are center- or surround-elicited.

The ON/OFF response characteristics of proximal neurons appear to be determined by excitatory inputs from two types of bipolar cells (Miller and Dacheux, 1976a, b; Naka, 1977). The anatomical stratification scheme of the dendrites of these neurons is consistent with the idea that they receive direct input from ON and OFF bipolar cell axon arbors within different regions of the IPL. This pattern has been seen in the retina of the cat (Nelson et al., 1981; Peichl and Wässle, 1981), teleost (Famiglietti et al., 1977) and mudpuppy (Zimmerman and Dowling, 1979).

It has been suggested that invaginating and flat-cone bipolar cell contacts represent the ultrastructural connections maintained by ON and OFF bipolar cells, respectively (Famiglietti and Kolb, 1976; Kolb, 1979; Nelson et al., 1981). Although this 


\section{GANGLION CELLS}

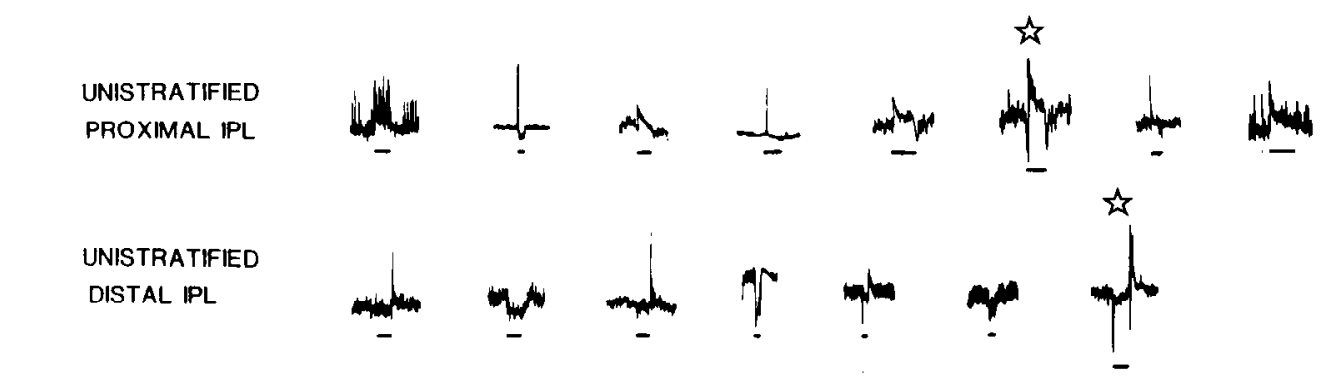

BISTRA TIFIED/DIFFUSE INNER/OUTER IPL

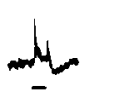

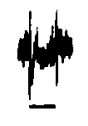

Figure 10. A summary of the 24 amacrine and ganglion cells examined in this study. Light responses were evoked by a diffuse $1 \mathrm{sec}$ light stimulus, with the duration indicated by the dark bars beneath each response. The level of dendritic stratification in the inner plexiform layer is indicated at the left. Only the ON-OFF ganglion cells showed bistratification of diffuse dendritic processes. For two ganglion cells marked with stars, see the Discussion.

UNISTRATIFIED

DISTAL IPL

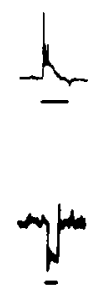

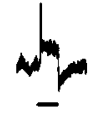

relationship can not be generalized for all vertebrates (Dacheux, 1982; Lasansky, 1978), it appears that the type of synapse that mammalian bipolars make with cones is indicative of their response polarity. Hence, the ON/OFF visual pathways may be formed at the very first synapse in the outer retina. How rod bipolars fit into the functional stratifications scheme is less certain. Nelson et al. (1978) have shown that rod bipolars of cat hyperpolarize to light, yet all end in proximal regions of the IPL. How, then, do rod signals become incorporated in the ON/ OFF pathways in the IPL? One possibility is that rod signals invade the cone pathways at the level of the photoreceptors via gap junctions between rods and cones (Raviola and Gilula, 1973). Second, Nelson and Kolb (1978) have shown that rod bipolars feed into special AII amacrine cells which, in turn, contact cone bipolar cells. Thus, rod signals may simply utilize the cone pathways to partake in the ON/OFF organization of the IPL. More recently, however, Dacheux and Raviola (1984) have described depolarizing rod bipolars in the rabbit that have overall cellular morpholugy and synaptic circuitry similar to those seen in the cat. Thus, there may exist both ON and OFF rod bipolars in mammalian retina, suggesting that rod pathways may maintain their own ON/OFF organization. Clearly, more studies will be required to delineate the relationship of rod pathways to the functional stratification scheme. It should be noted here that, in the present experiments, mesopic levels of illumination were usually used.

Our physiological criteria for ON vs OFF classification were based on the presence of EPSPs in amacrine and ganglion cell responses. In many ganglion cells, the presence of hyperpolarizing responses, whether inhibitory or disfacilitatory, can obscure the presence of an EPSP and thereby confuse the classification (see below). The amacrine cells did not show largeamplitude hyperpolarizing responses, so in those cells it was easier to assess the ON vs OFF character of thcir cxcitation. Thus, not only do ganglion cells participate in the ON/OFF stratification scheme, but all the amacrines that we stained could be unambiguously classified as $\mathrm{ON}$ or $\mathrm{OFF}$ - and all cells showed the appropriate stratification pattern. Although we did not study this type of neuron, ON-OFF amacrine cells in the rabbit retina, consistent with our findings, show bistratification of dendrites in both inner and outer IPL, as recently described (Coleman and Miller, 1984).

Among the amacrine cells in this study, perhaps the best characterized group are the starburst amacrines, first described by Famiglietti (1981). There is now general agreement that these neurons represent mirror-images of one another and constitute the ACh-releasing neurons described by Masland and Mills (1979), Tauchi and Masland (1983), and Vaney (1984). Our findings indicate that starburst amacrines with cell bodies in the inner nuclear layer are OFF cells, with their dendrites confined to the outer IPL. Starburst amacrines with cell bodies in the ganglion cell layer are ON cells, whose dendrites are within the proximal IPL. The response waveform of these cells is consistent with the idea that they receive either ON or OFF bipolar input, but not both. Thus no "ON-OFF" starburst amacrines have yet been seen; however, the comparatively small sample of cells in this study does not preclude the possibility that other physiological types of starburst amacrines may yet emerge.

\section{Inhibitory pathways and the functional stratification scheme}

It is abundantly clear that ganglion cells receive both inhibitory and excitatory inputs (Baylor and Fettiplace, 1979; Frumkes et al., 1981; Marchiafava and Weiler, 1980; Miller, 1980; Miller et al., 1977; Wunk and Werblin, 1979). Do the inhibitory inputs also conform to the functional stratification scheme? Figure 10 illustrates two ganglion cells (marked with stars), an ON cell and an OFF cell, both of which also display inhibition at light onset and offset. In either case, the ON/OFF scheme for inhibitory inputs is inconsistent with that for the excitatory input. Yet both of these cells display unistratified dendritic branching within that portion of the IPL appropriate for the polarity of 
the excitatory input. Thus, our findings are consistent with the idea that the dendritic stratification pattern of amacrine and ganglion cells seen in the rabbit retina implies, at the very minimum, the position of excitatory connections. Clearly, inhibitory inputs may not follow this scheme.

Does this mean that some inhibitory neurons, i.e., amacrine cells, do not stratify in that portion of IPL appropriate for the ON/OFF polarity of their response? That is, how does an ON cell receive inhibition at light offset? While the possibility of an OFF amacrine cell stratifying in the proximal IPL cannot be excluded, our data would argue against this. An explanation more consistent with our findings is that both the ON and OFF ganglion cells receive inhibition at light onset and offset via a diffusely, or bistratified, ON-OFF amacrine cell. While this is but one of many possibilities, it serves to illustrate how inhibitory signals can "cross" the ON/OFF pathways within the IPL while the presynaptic inhibitory neuron itself can still obey the functional stratification scheme.

\section{Problems with the ON vs OFF classification scheme}

When studying ganglion cells with extracellular recording techniques, it is usually not difficult to classify the cells as ON, OFF, or ON-OFF in polarity (Barlow et al., 1964). Intracellular recordings, however, sometimes present difficulties in determining the response polarity. One reason for this is that cell penetration often depolarizes the ganglion cell and eliminates impulse activity. In this case, the basic polarity of the cell must be determined on the basis of the PSP pattern. When the PSP pattern is a complex mixture of EPSPs and IPSPs, the latter can sometimes obscure the EPSPs (Frumkes et al., 1981). Thus some of the ganglion cell responses illustrated in this study could have been interpreted in different ways. It may be helpful, in future studies of this type, to block the inhibition with strychnine and/ or bicuculline in order to see the uninhibited excitatory connections. It is clear, however, that the sublamination pattern first described by Famiglietti and Kolb (1976) is highly useful in interpreting the ON and OFF organization of cone pathways. The work in this study is entirely consistent with the concept of a functional stratification scheme whose purpose is to make selective ON vs OFF inputs by third-order neurons. Since the cone bipolars terminate in different regions of the IPL, the fundamental ON and OFF pathways do not share the same extracellular milieu at the active neuropil regions.

A recent classification scheme of rabbit retinal ganglion cells has been presented by Amthor et al. (1983). All of our ganglion cells were rather large and, therefore, conform to their class I or II. The number of cells in our study is rather small, so we have not attempted more rigorous analytical procedures in an attempt to correlate our cells with other schemes.

Recently, Amthor et al. (1984) described the morphology of directionally selective cells in the rabbit retina. It is interesting to note that the morphology of the ON-OFF directionally selective ganglion cells is similar to that of those described in this study, despite the fact that we did not find these ON-OFF cells to be directionally selective. This may indicate that it is not the morphology of the dendrites per se that determines such selectivity, but rather the nature and order of the synaptic connections.

\section{References}

Amthor, F. R., C. W. Oyster, and E. S. Takahashi (1983) Quantitative morphology of rabbit retinal ganglion cells. Proc. R. Soc. Lond. [Biol.] 217: 341-355.

Amthor, F. R., C. W. Oyster, and E. S. Takahashi (1984) Morphology of on-off direction-selective ganglion cells in the rabbit retina. Brain Res. 298: 187-190.

Barlow, H. B., R. M. Hill, and W. R. Levick (1964) Retinal ganglion cells responding selectively to direction and speed of image motion in the rabbit. J. Physiol. (Lond.) 173: 377-407.
Baylor, D. A., and R. Fettiplace (1979) Synaptic drive and impulse generation in ganglion cells of turtle retina. J. Physiol. (Lond.) 288 : 107-127.

Bloomfield, S. A. (1981) A physiological-morphological study of neuronal pathways in the rabbit retina. Ph.D. thesis, Washington University, St. Louis, MO.

Bloomfield, S. A., and R. F. Miller (1981) Functional stratification of ON and OFF pathways in the rabbit retina. Invest. Ophthal. Vis. Sci. (Suppl.) 20: 13.

Bloomfield, S. A., and R. F. Miller (1982) A physiological and morphological study of the horizontal cell types of the rabbit retina. J. Comp. Neurol. 208: 288-303.

Caldwell, J. H., and N. W. Daw (1978) New properties of rabbit retinal ganglion cells. J. Physiol. 276: 257-276.

Coleman, P. A., and R. F. Miller (1984) The electroanatomy of the rabbit ON-OFF amacrine cell. Soc. Neurosci. Abstr, 10:325.

Dacheux, R. F. (1977) A physiological study of the ontological formation of synaptic interactions in the rabbit retina. Ph.D. thesis, SUNY at Buffalo, Buffalo, NY.

Dacheux, R. F. (1982) Connections of the small bipolar cells with the photoreceptors in the turtle. An electron microscope study of Golgiimpregnated, gold-toned retinas. J. Comp. Neurol. 205: 55-62.

Dacheux, R. F., and E. Raviola (1984) Physiology and anatomy of a rod bipolar and amacrine cell in the rabbit retina. Invest. Ophthal. Vis. Sci. (Suppl.) 25: 203.

Dacheux, R. F., M. Delmelle, R. F. Miller, and W. K. Noel (1973) Isolated rabbit retina preparation suitable for intra- and extracellular analysis. Fed. Proc. 32: 327.

Dacheux, R. F., T. E. Frumkes, and R. F. Miller (1979) Pathways and polarities of synaptic interactions in the inner retina of the mudpuppy: I. Synaptic blocking studies. Brain Res. 161: 1-12.

Dierker, M. L. (1980) Three dimensional reconstruction of neurons from serial sections. Ph.D. thesis, Washington University, St. Louis, MO.

Famiglietti, E. V. (1981) Starburst amacrines: 2 mirror-symmetric retinal networks. Invest. Ophthal. Vis. Sci. (Suppl.) 20: 209.

Famiglietti, E. V. (1983) 'Starburst' amacrine cells and cholinergic neurons: Symmetric ON and OFF amacrine cells of rabbit retina. Brain Res. 261: 138-144.

Famiglietti, E. V., and H. Kolb (1976) Structural basis for the on and off center responses in retinal ganglion cells. Science 194: 193-195.

Famiglietti, E. V., and E. C. Siegfried (1980) The amacrine cells of rabbit retina. Soc. Neurosci. Abstr. 19: 6.

Famiglietti, E. V., A. Kaneko, and M. Tachibana (1977) Neuronal architecture of on and off pathways to ganglion cells of the carp retina. Science 198: 1267-1269.

Frumkes, T. E., R. F. Miller, M. Slaughter, and R. F. Dacheux (1981) Physiological and pharmacological basis for GABA and glycine actions on neurons of the mudpuppy retina. III. J. Neurophysiol. 45: 783-804.

Ilartline, II. K. (1938) The response of single optic nerve fibers of the vertebrate eye to illumination of the retina. Am. J. Physiol. 121:400415.

Hughes, A. (1971) Topographical relationships between the anatomy and physiology of rabbit visual system. Doc. Ophthalmol. 30:33159.

Kaneko, A. (1970) Physiological and morphological identification of horizontal, bipolar and amacrine cells in goldfish retina. J. Physiol. (Lond.) 207: 623-633.

Kolb, H. (1979) The inner plexiform layer of the retina of the cat: Electron microscopic observations. J. Neurocytol. 8: 295-329.

Lasansky, A. (1978) Contacts between receptors and electrophysiologically identified neurones in the retina of the larval tiger salamander. J. Physiol. (Lond.) 285: 53-69.

Marchiafava, P. L., and R. Weiler (1980) Intracellular analysis and structural correlates of the organization of inputs to the ganglion cells in the retina of the turtle. Proc. R. Soc. Lond. [Biol.] 208: 103-113.

Masland, R. H., and J. W. Mills (1979) Autoradiographic identification of acetylcholine in the rabbit retina. J. Cell Biol. 83: 159-178.

Mesulam M.-M. (1976) The blue reaction product in horseradish peroxidase neurohistochemistry: Incubation parameters and visibility. J. Histochem. Cytochem. 24: 1273-1280.

Miller, R. F. (1979) The neuronal basis of ganglion cell receptive field organization and the physiology of amacrine cells. In The Neurosciences Fourth Study Program, MIT, Cambridge, MA.

Miller, R. F. (1980) On the electroanatomy of amacrine and ganglion cells. Invest. Ophthal. Vis. Sci. (Suppl.) 19: 5. 
Miller, R. F., and S. A. Bloomfield (1983) Electroanatomy of a unique amacrine in the rabbit retina. Proc. Natl. Acad. Sci. USA 80: 30693073.

Miller, R. F., and R. Dacheux (1973) Information processing in the retina: Importance of chloride ions. Science 181: 266-268.

Miller, R. F., and R. Dacheux (1975) Chloride-sensitive receptive field mechanisms in the isolated retina-eyecup of the rabbit. Brain Res. 90: 329-334.

Miller, R. F., and R. F. Dacheux (1976a) Synaptic organization and the ionic basis of on and off channels in the mudpuppy retina. II. Chloride-dependent ganglion cell mechanisms. J. Gen. Physiol. 67: 661-678.

Miller, R. F., and R. F. Dacheux (1976b) Synaptic organization and the ionic basis of on and off channels in the mudpuppy retina. III. A model of ganglion cell receptive field organization based on the chloride-free experiments. J. Gen. Physiol. 67: 679-690.

Miller, R. F., R. Dacheux, and R. Frumkes (1977) Evidence for independent GABA and glycine releasing amacrine cells in mudpuppy retina. Science 198: 748-750.

Naka, K. I. (1977) Neuronal circuitry in the catfish retina. Invest. Ophthal. 15: 926-935.

Nelson, R., and H. Kolb (1978) Small field amacrines in the rod system of the cat retina. Invest. Ophthal. Vis. Sci. (Suppl.) 17: 110.

Nelson, R., E. V. Famiglietti, and H. Kolb (1978) Intracellular staining reveals different levels of stratification for on- and off-center ganglion cells in cat retina. J. Neurophysiol. 41: 472-483.

Nelson, R., H. Kolb, M. Robinson, and A. Mariani (1981) Neural circuitry of the cat retina: Core pathways to ganglion cells. Vis. Res. 21: $1527-1536$
Peichl, L., and H. Wässle (1981) Morphological identification of onand off-centre brisk transient (Y) cells in the cat retina. J. Physiol. (Lond.) 212: 139-156.

Raviola, E., and N. B. Gilula (1973) Gap junctions between photoreceptor cells in the vertebrate retina. Proc. Natl. Acad. Sci. USA 70. 1677-1681.

Slaughter, M. M., and R. F. Miller (1981) 2-Amino-4-phosphonobutyric acid: A new pharmacological tool for retina research. Science 211: 123-185.

Tauchi, M., and R. Masland (1983) The shape of the cholinergic amacrine cells in the rabbit: Identification by injecting fixed, fluorescent neurons. Soc. Neurosci. Abstr. 9: 895.

Vaney, D. I. (1984) "Coronate" amacrine cells in the rabbit retina have the "starburst" dendritic morphology. Proc. R. Soc. Lond. [Biol.] 220 501-508.

Wann, D. F., T. A. Woolsey, M. L. Dierker, and W. M. Cowan (1973) An on-line digital computer system for semiautomatic analysis of Golgi-impregnated neurons. IEEE, Trans. Biomed. Eng. 20: 223-247.

Werblin, F. S., and J. E. Dowling (1969) Organization of the retina of the mudpuppy, Necturus maculosus. II. Intracellular recording. J. Neurophysiology 34: 228-241.

Wunk, D. F., and F. S. Werblin (1979) Synaptic inputs to the ganglion cells in the liger salamander retina. J. Gen. Physiol. 73: 265-286.

Zimmerman, R. P., and J. E. Dowling (1979) Functional stratification of the IPL of the mudpuppy retina. Invest. Ophthal. Vis. Sci. (Suppl.) 18: 35 . 